\title{
Correction to: Effects of organic amendment on some soil physicochemical characteristics and vegetative properties of Zea mays in wetland soils of the Niger Delta impacted with crude oil
}

\author{
Francis E. Egobueze ${ }^{1} \cdot$ Josiah M. Ayotamuno ${ }^{2} \cdot$ Chukwujindu M. A. Iwegbue $^{3} \cdot$ Chibogwu Eze $^{1}$. \\ Reuben N. Okparanma ${ }^{2}$
}

Published online: 27 December 2019

(c) The Author(s) 2019

\section{Correction to: International Journal of Recycling of Organic Waste in Agriculture https://doi.org/10.1007/s40093-019-00315-6}

In the original publication of the article, the author's name Reuben N. Okparanma was misspelled as "Ruben N. Okparanma". The original article has been updated.

Open Access This article is licensed under a Creative Commons Attribution 4.0 International License, which permits use, sharing, adaptation, distribution and reproduction in any medium or format, as long as you give appropriate credit to the original author(s) and the source, provide a link to the Creative Commons licence, and indicate if changes were made. The images or other third party material in this article are included in the article's Creative Commons licence, unless indicated otherwise in a credit line to the material. If material is not included in the article's Creative Commons licence and your intended use is not permitted by statutory regulation or exceeds the permitted use, you will need to obtain permission directly from the copyright holder. To view a copy of this licence, visit http://creativecommons.org/licenses/by/4.0/.

The original article can be found online at https://doi.org/10.1007/ s40093-019-00315-6.

Chukwujindu M. A. Iwegbue

maxipriestley@yahoo.com

1 Institute of Geoscience and Space Technology,

Port Harcourt, Nigeria

2 Department of Agricultural and Environmental Engineering,

Rivers States University of Science and Technology,

Nkpolu-Oroworoko, Port Harcourt, Nigeria

3 Department of Chemistry, Delta State University, P.M.B. 1, Abraka, Delta State, Nigeria 